\title{
A REVIEW OF SOME ASPECTS OF THE CORRELATION BETWEEN PEDAGOGY AND POLITICS
}

\begin{abstract}
Education and upbringing, as a subject of the pedagogy in the wider meaning of the term, have always been of special social and state interest. The state, with its instruments of government, has strived to carry out its politics in the field of education and upbringing. The word politics is associated with the terms state, state affairs, affairs of a state's interest. This interest is very explicitly expressed in the function and the structure of the school and the school system, especially for satisfying the fundamental needs of every state.

In this paper some interpretations of the terms politics of education and education policy are given, pointing out the differences in their treatment and meaning. It has been stressed that pedagogy has an autonomous position regarding the state's educational-upbringing policy and the political factors, exponents of this policy. It has critical attitude towards the politics and the political conception of the goals, and is also autonomous from the educational-upbringing practice, having a critical attitude towards it too, since any educational-upbringing practice cannot be a source of pedagogical cognition and raise to the level of theory which, from that position, is going to advance the pedagogical practice. In this respect the issue of the correlation between politics and pedagogy is reviewed by their structure: policy (educational-upbringing policy), pedagogy (science, theory), educational-upbringing practice (pedagogical practice).

In these processes and correlations there must be a permanent questioning and valorisation of the educational-upbringing policy, especially of its goals and educational strategy and practice, as well as of the postulates, models and instruments the pedagogy as a science offers. The realization of the goals in the development of educational-upbringing systems must be compatible with the directions of the development of education at global level, but nevertheless, the success depends on the social, cultural, economic and educational context of the particular state.
\end{abstract}

Keywords: PEDAGOGY, POLITICS, EDUCATION POLICY, DEVELOPMENT, CHANGES, EDUCATIONAL-UPBRINGING SYSTEM

In the process of viewing the current issues aroused by the changes at global, as well as at a particular society's level, pedagogy as a science of education and upbringing tries to answer some fundamental questions essential for 
functioning and improving the education and upbringing in the conditions of social changes.

Education and upbringing as a subject of the pedagogy in the wider meaning of the term, have always been of special social and state interest. This interest is specially emphasized, since in a most immediate and organized way it is realized through the school and the school system which have been created by the state for satisfying that interest. In the course of the human society's development, education and upbringing have been different by their essence and characteristics, that is they have depended on the class and other types of social relations and have been oriented to correspond to the politics of the particular society as much as possible. The state, as an instrument of government of the ruling class, has strived to carry out its politics in the sphere of education and upbringing.

Regarding the definition of the term politics, many authors give their own definitions, therewith contributing to authentic interpretation of that term.

In example, Pašić gives a complex, generalized and wide definition of politics, which says: "The politics includes all the forms and types of deliberate social actions that provide resolution of all the social contrasts in the process of performing certain common social functions with the goal of connection or integration of the individualized parts (both individuals and groups) into one functionally organized entity of the global society, based on a certain form of material production and reproduction of the social life." (Pašić, 1976: 40)

Another definition of politics defines it as a social activity consisting of deliberated determination of the human activity goals and the instruments for these goals' realization, in all the spheres of the social life (Lukić, 1982: 14). The term politics refers to the activities of the government as a response to the social problems (Đorđević, 2009). The public politics includes not only what the government does, but also what it doesn't do, which also has certain consequences (Dye, 2013). The politics has also been defined as an "authoritative distribution of the values", and, accordingly, "authoritative values" are those which are widely accepted within the society, where most of the citizens take them as obligatory. In this respect, the word politics is associated with the word policies, that is - with the formal or authoritative decisions by which the action plan of the society is established.

In English language there are three words referring to this kind of organized social activity - polity, politics and policy, denoting its three aspects/dimensions, while in many other languages (e.g. German, French, Italian, Spanish, Serbian, Macedonian) there is only one word (politika in Macedonian language) for all the three aspects, and that's why they are much harder to distinguish. The word polity denotes the political order in a community/society, its state structure i.e. its institutional and normative framework where the politics as a process takes place. The word politics refers to the political process itself, that is realization of a political structure's interest within the society by the means of confrontations and reaching consensus. The word policy denotes the 
activities of specific decision-making in different spheres of the public sector. This term denotes the material side of the politics, that is it refers to the goals, postulates, contents and consequences of the public decision-making, and above all to the functional aspects of the politics (Stančetić, 2015: 20).

The key terms related to the polity dimension, are: state, constitution, human rights, political system, political culture. The politics dimension is related with these terms: interests, actors, conflict, consensus, legitimacy and authority. Terms characteristic for the policy dimension, are: social problems, action plans, success (in a certain activity) (Miljković, 2014: 16-24). In general, the distinction between these three terms can be reduced to these essentials: distinguishing the form, the process and the contents. The word politics actually covers all the three dimensions: an action which happens within a framework and a context (polity), takes place as a process (politics) and has its contents (policy). In the case of education, it is a matter of the contents of the education policy, the process of its formulation, and the conditions and the context where it takes place (Miljković, 2014: 34).

As we have already said, the very word politics is associated with the terms state, state affairs, affairs of a state's interest. Accordingly, the state interest is also a political interest. This interest is very explicitly expressed in the function and the structure of the school and the school system, especially for satisfying the fundamental needs of every state, namely: First, the school as a core and the school system as a whole reproduce skilled personnel so that the political, economic and the value systems of the state could function successfully. Second, performing that function they satisfy two special needs: to provide stability of the state's functions (conservative need), and to provide development of the state and its organization as well as its continuous reform (progressive need). In what proportion these two needs (conservative and progressive) are going to be satisfied, largely depends on the state's character - whether it is of democratic or of totalitarian type.

The upbringing efforts in different societies can be oriented in diametrically opposite directions, i.e. towards the individual or towards the society, towards teaching to independence or teaching to conformism, towards development of critical thinking or towards passive acceptance of the imposed attitudes with the goal of manipulating the person.

Polić stresses that "democratic societies can be recognized by the upbringing, and the non-democratic by the manipulation and ideological indoctrination". From this context arouses the difference between upbringing and manipulation, which reflects in their goals. "The goal of the manipulation is functional adaptation of the object of manipulation, i.e. the person brought-up, whereas the goal of upbringing is satisfaction of the needs of the educator and the bringing-up person." (Polić, 1993: 21)

In this line are also the deliberations of Marinković, who calls the pedagogy "an apology of the existing" since he thinks that pedagogy creates personalities according to the authorities' needs, imposes ideas about life and world 
the way the state likes to be and not the way they really are. This way, he thinks, two different upbringing realities are made - one, the state wants to create through the schools, and other, created by the real life. "Creating what the state wants, the school doesn't bring up, it doesn't create freedom, but quite the opposite - non-freedom." (Marinković, 1987: 82) Unfortunatelly, in the mankind's history this has been shown true during the rule of totalitarian regimes and is still reflected in the non-democratic societies.

That's why Marinković points out that, if the pedagogy really wants to bring up, it has to be a critic of the existing, and shall build the future by preserving all that has been shown valuable so far and rejecting what is unworthy for the future. And if it is so, this is a true pedagogy, which by itself and above all is a critique of the existing." (Marinković, 1987: 81)

The politics in the field of education and upbringing is carried out by the politicians (through laws, institutions), and pedagogues are the immediate realizers of the pedagogical, education-upbringing policy. The models of pedagogic instruments and methods for achieving these goals have been theoretically and normatively elaborated and founded by the pedagogy (as a theory and science) which also examines whether the pedagogical practice corresponds to the existing goals and concepts, as well as how efficient the instruments and methods are. However, the pedagogy has a critical attitude also towards the goals and the concepts from the aspect of the fundamental criteria of the humanistic pedagogy i.e. how much they are in accordance with the complete and humane development of the brought-up person as a subject in the educational-upbringing process.

The pedagogy is autonomous regarding the education-upbringing policy of the state and the political exponents of that policy, having a critical attitude regarding that policy and the political concept of the goals, and is also autonomous from the educational-upbringing practice having a critical attitude regarding it too, since any kind of educational-upbringing practice cannot be a source of pedagogical cognition and raise to the level of theory which is going to improve the pedagogical practice.

In this respect, we can imagine, in a simplified manner, the issue of the relation between politics and pedagogy as a structure made of policy (education-upbringing policy), pedagogy (science, theory) and educational-upbringing practice (pedagogical practice).

The education-upbringing policy emanates from the wider context of the general politics created by the state or the ruling political forces in a certain period of time through the legislative and executive authorities. Such a policy in the modern, developed and democratic societies is largely founded on the own scientific insights of those sciences which perform their own theoretic and empiric researches relevant to the particular politics. Among these sciences, in example, are the: economy, demography, sociology, sociology of education and comparative pedagogy. Since the fundamental educational-upbringing institution in the organized school system is the school itself, of special importance 
for the education-upbringing policy is the theory of school and the school pedagogy which is today a highly developed discipline within the system of pedagogical scientific disciplines.

According to this, the education-upbringing policy in today's developed society overcomes its voluntarist nature characteristic of authoritarian regimes and becomes a qualified user of the scientific knowledge from many fields, including pedagogy too.

However, in the scientific field there are no uniform solutions for all the social conditions (regarding the possible practice). The sciences and the pedagogy offer many theoretical bases and models, and it is up to the politics as to which ones to choose and what kind of social ambient it will create for their realization and by what dynamics.

In these processes and relations there must be a permanent revision and valorisation of the education-upbringing policy, especially of its goals and strategy, and the educational-upbringing practice as well as the postulates, models and instruments the pedagogy as a science offers. However, in all this interdependence and coordination, all these factors have a relative autonomy and responsibility. Pedagogy builds its autonomy by permanent criticism of both the policy and the educational-upbringing practice, using its own scientific criteria and methodology. The politics questions its goals and practice, and has a wider social responsibility as well as a liability for all the possible consequences regarding its ruling position.

However, the politics must not impose ideological frameworks and directives to the sciences and be their judge, since in the sciences the political or the ideological criteria are not important, but the rigorous scientific criteria. That's why the science is always its own judge, at the same time being socially responsible with its scientific knowledge to promote the social practice, above all from humanistic positions. The pedagogy has such responsibility and engagement in the field of educational-upbringing practice.

Viewing the issues in the relations politics-pedagogy and having insight in the relevant literature in this field, differences can be noticed regarding the treatment of the terms politics of education and education policy, namely their different meaning is pointed out. However, the use of only one of these two terms can also be noticed, with the remark that these terms (constructions) are connected and can hardly be viewed separately, especially when it comes to the educational-upbringing activity. In the explanation of the difference in the meaning of these two terms, it has been pointed out that we can speak of politics of education when it comes to the process of managing the educational processes and defining the desired future, while the education policy refers to the steps and activities undertaken for the realization of all this. The politics of education is based on a certain educational philosophy or educational concept, the formulated goals for development of the education and the educational system, a vision of the education, as well as strategic and developmental orientations, whereas the education policy includes the mechanisms by which the 
conditions (legal, financial, personnel...) for the realization of the educational goals and strategies are provided (Alibabić, Miljković, Ovesni, 2012: 10,11).

Similarly, Dale points out that the term politics of education refers to the structure and the process by which the wider social expectations from the education are identified and interpreted and that they constitute the basis for the functioning of the educational system, while the term education policy refers to the processes by which that idea (agenda) is transferred to the issues and the problems relevant for the functioning of the schooling institutions and the course of the schooling practice, as well as their response to the questions and problems given (Dale, 1994: 35-36). In his opinion, the education policy cannot be understood if it is not brought in correlation with the politics of education.

In the sociological and politicological literature the terms education policy, educational strategy etc., are used more frequently.

Having in mind the pedagogical approach, we opted for the term education-upbringing policy since we think that education and upbringing are complementary, not only as pedagogical, but also as social functions. However, the authors which use the term education policy, under this term also understand in a certain degree the upbringing component too. Very often, with the same meaning is used the term enlightenment policy.

Education policies are inseparable from the issue of values too. The decisions in the domain of education policies always rest on a certain system of values, so that sometimes the conception is stressed that the education policies are a valuationally oriented action (Jones, 2013). The values are explicitly or implicitly included in the decisions brought and the measures undertaken. Education policy has traditionally been in the province and competence of national states, and the values on which it was based have been mostly linked to the national interests. However, in the past period of time, under the influence of globalization and with the mediation of international actors (in example: OECD, The World Bank, UN, European Union), a strong influence has been noticed of the global trends in the education on the creation of national education policies in many countries in the world. Therewith, certain values based on the neoliberal economy and market principles have entered the field of education (Ball, 2006). Efficiency, effectiveness, competitiveness, development of competencies for a labour market and so on, have been more accentuated, which way the values characteristic of humanistically oriented education have been put in the background. So, under the influence of political, social, economic and cultural conditions in the society, the education policy is strongly influenced by the wider global trends, a trend becoming more and more pronounced nowadays.

In one of the older, but very important analytical study made by UNESCO, To Learn for Life or The World of Education Today and Tomorrow, the terms education policy and education strategy are used. There it is stressed that "every education policy reflects the political tenets of a particular country, its traditions and values, and concepts about its future... and this is a function belonging to the national sovereignty of every state" (Faure, 1975). 
In the process of creating an education policy it is not enough only to bring forward, to proclaim "a few general leading principles", but also "the whole structure of the specific goals" must be very widely elaborated, which includes the goals, common to the mankind, of spiritual, philosophic and cultural nature, as well as the political goals appropriate to the interests and the desires of the national community; the social economic goals; the wider educational goals; and, finally, the narrower educational goals concerning the school system, its levels and interactions (Ibid).

Beside this, the education policy requires not only a quotation of the goals set, but also their classification according to the priority. And not only that, but also the education goals in correlation and accordance with all the other social goals.

In this study are given certain directives for the elaboration of an education strategy which ought to satisfy not only the requirements of the policy, but also the requirements of the planning process.

In the first case, the education strategy must be global (to include all the forms and levels of education); integrated in the other systems of the politics' (both social and economic) goals; and, in some extent, of long-term character, according to the pace of the political alternatives which are going to arise.

In the second case (regarding the requirements of the planning process), the education strategy must be specific so that it could respond to the technical requirements of the planning and the dynamics in order to be able of taking into account the creative process of evolution and innovations which may change the basic information known at the beginning.

"The goal of planning is to ease bringing the decisions at different levels where the strategic directives must be implemented." This requires "a combination of ways and instruments for realization of the policy", and because "the social reality is in a state of permanent changes ... the planning must be a continuous operation". However, such planning must not be dictatorial or equate the versatile with the totalitarian planning. According to this, a logical process would be the one "that moves from policy towards strategy, and from strategy towards planning" (Ibid).

Regarding the characteristics of the educational strategies, it is stressed that the strategy oriented by "the principles of linear expansion of the system and the number of covered population" is now obsolete, since today it is hard to make forecasts in such a dynamic field like education. Quantitative methods are good only for stable educational systems. But for today's dynamics which requires qualitative changes, higher efficiency of the educational activity, overcoming the existing balance in the education system, internal qualitative pedagogical reform of the school, orientation towards looking for innovations, the strategy of linear expansion of the mechanical extrapolation is now obsolete because it does not include the qualitative aspects of the education system. For this reason, an orientation towards alternative educational strategies is neces- 
sary, among else also because the education goals by definition cannot be limited to quantitatively determined achievements which are especially related to the goals of employment and self-employment. By definition, the "education goals must also correspond to the development of the individuals in their narrower and wider environment (the society) which can only be a nation or various territories constituting a nation, and they must include finding solutions to the problems influencing the community's organization and the intercommunal, interethnic and linguistic relations, etc." (Ibid, 204).

This study done by UNESCO suggests to affirm alternative educational strategies which shall include integrated educational goals favouring the ecological approach (every school system is a component of the environment where the individual and the goups develop), the contents of the programmes and the pedagogical methods must be diversified according to the environment, thus requiring the development of educational activities out of the school too. The social and life environment are not limited to the school. The education and upbringing problems cannot be resolved separately, but only within the wider social system and that's why the educational strategies limited only to the educational system are inappropriate. On the other hand, very indicative and categorical are the assertion and the message that "wrongly is if the education, or only its schools and system, is regarded only as a manifestation of the social forces in power, the state or the regiment, excluding all the other complementary, independent or hostile factors in the society". Very important and influential in determining the education goals and their modification are especially "the pedagogical thought, the philosophy, theory and science of education, and the ideology in general". That's why it happens "the world of education, especially the school, to be an arena of perpetual arguments and confrontations" in the process of determining the education's directions and goals. No democratic society can harmonize the wider social interests without respecting this fact (Ibid, 205).

The changes in the society brought a lot of new opportunities, as well as problems that must be resolved. In the report on the education, made by UNESCO in 1996, titled: Learning: The Treasure Within, it has been stressed that in order the education and upbringing to be able to materialize its tasks, to influence the young people's personal development in the direction of encouraging them to acquire the necessary knowledge and skills at the same time preparing for life in society, a necessity is to overcome the confrontations existing between: global and local, universal and individual, spiritual and material, modern and traditional, long-term and short-term, competitiveness and equal opportunities for everybody, and enormous increase of the knowledge and people's abilities and capacities to master that knowledge.

By overcoming these contrasts, the need arises of enabling every individual, through the educational-upbringing process, to develop his/her abilities, to arrive to the own maximal potentials, to develop own identity, autonomy and sense of affiliation, respecting the own nation, traditions and culture, 
at the same time raising and shaping as the world's active citizen ready to face the new challenges, to adapt to the new conditions, and to be oriented towards development and progress, at the same time always remaining worthy of and devoted to the own values and ideals.

According to UNESCO, the noblest task of the education and upbringing, on which the survival of the mankind depends, is every one to get connected with the spiritual and the universal, at the same time respecting the one's own traditions and beliefs, on one hand, and the pluralism, on the other (UNESCO, 1996: 17).

Consequently, the UNESCO Commission defines the four pillars i.e. fundaments of education and upbringing. These four pillars are: learning to know, learning to do, learning to be and learning to live together.

- Learning to know - it refers to the need of having a wider general knowledge and profound professional skills, which form the basis of lifelong learning. It also means learning how to learn, which, by its side, is a condition for adaptation to the swift changes and adoption of new knowledge and achievements.

- Learning to do - it refers to the need of acquiring the competencies necessary for work in various situations and conditions.

- Learning to be - this pillar refers to the need of every student to possess a developed ability of critical thinking and judgement and independence, which includes developed abilities of memorization, deliberation and imagination; physical skills; sense of aesthetics; ability of communication with other people and ability of being a leader.

$\circ$ Learning to live together - it refers to the necessity of understanding and apprehension of other people, their culture, values and tradition, as a base for mutual cooperation and successful resolution of the problems. However, the UNESCO Commission report notes that, according to some authors, this is a Utopia, but nevertheless a Utopia necessary to the modern society (UNESCO, 1996: 21).

By this, UNESCO's intention is to point out that "despite all the problems and misfortunes caused by wars, internal conflicts and crime, there is another, better way on which the education ought to lead us through its moral and cultural dimensions" (UNESCO, 1996: 17).

Another very important UNESCO programme is the Dakar Framework for Action: Education for Everyone, from 2000, which defines a comprehensive policy on education's development, and suggests directives for action and mechanisms for follow-up of the results. The goals include spreading and promoting the pre-school upbringing, universal coverage by primary education, overcoming the gender differences in the educational process and improvement of education's quality (UNESCO, 2000).

UNESCO's document brought in 2015, Rethinking Education: Towards a Global Common Good, chiefly points out the changes in the modern world and 
the man's progress, on one hand, and the increase of conflicts, tensions and poverty, on the other. Therefrom, this situation and many other problems that concern all the world, pose in front of us the question: What kind of education do we need for the $21^{\text {st }}$ century?

This document points out the importance and the need of reaffirmation of the humanistic values, emphasizing that the dominant utilitarian concept of the education must adopt a different view on the human well-being and focus on the importance of the education as a common good. This document is a humanistic vision based on these premises: Reaffirmation of ethnic principles as a fundamental approach in the education; The learning must be flexible and transformative, and the education must include development of critical thinking and independent judgement as well as willingness for dialogue; To involve inclusiveness; The education ought not only to have a utilitarian purpose in the function of economic development, although the economics function is very important too, and it shouldn't be a sheer acquisition of skills, but it is a matter of values of respecting the human individual and the human dignity, necessary for the social harmony in the world of diversities.

It is quite clear that the realization of the goals in the development of the educational-upbringing systems must be compatible with the directions of the education's development at global level, however, the success still depends on the cultural, economic and educational milieu in the country. The changes in the sphere of education must be created and conducted in line with the characteristics of that milieu, i.e. with the conditions in which the educational-upbringing work is done, the specific educational needs and the actual possibilities for their realization. Education and upbringing in the schools are not a practice isolated from the overall social milieu, on the contrary - they consist the political platform which prepares the subjects for engagement in what is called common (commune, Gemeinsames) or political. These platforms have been and have remained decisive for a subject's formation and his/her positioning in the society.

For this reason it is necessary, in the approach to the reforms in the education, to recognize and choose those steps and activities which are real and achievable in the own ambience, and which will be sustainable and will give positive results on the long run.

\section{References:}

AliBABIĆ, Š., MiLJKOVIĆ, J., \& OvESNI, K. (2012). Obrazovanje odraslih u regionalnim obrazovnim politikama. U: Vujisić Živković, M. Mitrović i K. Ovesni (ur.), Posebna pitanja kvaliteta u obrazovanju (str. 9-25). Beograd: Institut za pedagogiju i andragogiju, Filozofski fakultet Univerziteta u Beogradu.

BALL, S. (2006). Education Policy and Social Class. London: Routledge.

BALL, S. (2017). The Education debate (Third Edition). Bristol: Policy Press 
DYE, T. (2013). Understanding public policy. New York: Pearson

DALE, R. (1994). Applied education politics or political sociology of education? Contrasting approaches to the study of the recent education reform in England and Wales. In D. Halpin and B. Troyna (Eds.), Researching Education Policy: Ethical and Methodological Issues (pp. 31-41). London: Falmer Press.

Delors, J., Al Mufti, I., Amagi, I., CARneiro, R., Chung, F., GeremeK, B., Gorham, W., Kornhauser, A., Manley, M., Padrón Quero, M., SAVAnÉ, M. -A., Singh, K., Stavenhagen, R., Won Suhr, M., NANZHAO, Z. (1996). Učenje: blago u nama. Izvješće UNESCO-u međunarodnog povjerenstva za razvoj obrazovanja za 21. stoljeće. Zagreb: Tipotisak d.o.

EASTON, D.(1979). A Framework for Political Analysis (2 ${ }^{\text {nd }}$ ed.). Chicago: University of Chicago Press.

EASTON, D.(1981).The Poliyical System (3 ${ }^{\text {nd }}$ ed.). Chicago: University of Chicago Press.

Faure, E., Herrera, F., Kaddoura, A.-R., Lopes, H., Petrovsky, A. V./ RAhneMA, M., WARD, F. C. (1975). Učiti za život: svet obrazovanja danas $i$ sutra. Beograd: Stručna štampa.

JONES, T. (2013). Understanding Education Policy. Dordrecht: Springer.

ĐorĐEVIĆ, S. (2009). Analiza javnih politika. Beograd: Fakultet političkih nauka.

LUKIĆ, R. (1982). Istorija političkih i pravnih teorija. Beograd: Nučna Knjiga.

MARINKOVIĆ, J. (1987). Ogledi iz filozofije odgoja. Zagreb: Školske novine.

MiLJKOVIĆ, J. (2014). Evropska obrazovna politika i upravljanje sistemom obrazovanja odraslih. Beograd: Filozofski fakultet Univerziteta u Beogradu (doktorska disertacija- PDF)

google.com/search?q=Miljković\%2C+J.+(2014).+Evropska+obrazovna+polit ika+i+upravljanje+sistemom+obrazovanja+odraslih\&oq=Miljković\%2C+J.+ (2014).+Evropska+obrazovna+politika+i+upravljanje+sistemom+obrazova nja+odraslih\&aqs=chrome..69i57.1224j0j7\&sourceid=chrome\&ie=UTF-8

PAŠıć, N.(1976). Klasa i politika. Beograd: Rad.

Polić. M. (1993). K filozofiji odgoja. Zagreb: > Znamen<, Institut za Pedagogijska istraživanja Filozofskog fakulteta Sveučilišta u Zagrebu.

STANČETIĆ, V. (2015). Reforma javne uprave: ka novoj javnoj upravi. Beograd: Fakultet političkih nauka i Čigoja.

UNESCO (2000). The Dakar Framework for Action. Paris: UNESCO.

UNESCO (2015): Rethinking education. Towards a global common good? Paris: UNESCO. Retrieved April 23, 2020 from the World Wide Web http://unesdoc.unesco.org/images/0023/002325/232555e.pdf

UNESCO (n.d.). UNESCO in Brief - Mission and Mandate. Retrieved March 24, 2020 from the World Wide Web https://en.unesco.org/

UNESCO (n.d., a). The Universal Declaration of Human Rights. Retrieved April 5, 2020 from the World Wide Web 
http://www.unesco.org/education/information/50y/nfsunesco/doc/humrights.htm

UNESCO (n.d., b). Incheon Declaration Education 2030: Towards Inclusive and Equitable Quality Education and Lifelong Learning for All. Retrieved April 10, 2020 from the World Wide Web

https://unesdoc.unesco.org/ark:/48223/pf0000233813 